\title{
Precarious Care Labor: Contradictory Work Regulations and Practices for Au Pairs in Sweden
}

\section{Terese Anving'}

PhD and Researcher, Department of Sociology, Lund University, Sweden

I Sara Eldén

PhD and Assistant Senior Lecturer, Department of Sociology, Lund University, Sweden

\begin{abstract}
This paper focuses on the rules and regulations relating to au pair work in Sweden, and how these rules correlate with au pairing practices. The precarious position of au pairs has been highlighted before, but in addition, au pairs coming to Sweden also find themselves in an unclear work situation due to contradictory rules and regulations. While au pairs from outside the EU must apply for a work permit that defines their work as cultural exchange, this regulation does not apply to EU au pairs. As a consequence, we currently see the emergence of an almost completely unregulatedand growing - market for au pairing in Sweden. Drawing on a qualitative study of the private child care market in Sweden, this paper analyzes rules and regulations for au pairing, as well as how au pair working conditions are understood, negotiated, and realized by employing parents, and au pairs themselves. This is analyzed in relation to theoretical elaborations of paid and unpaid work, as well as discussions of care as a practice where 'work' and 'emotion' is inherently intertwined.
\end{abstract}

\section{KEY WORDS}

Au pair / care / family / migration / work

DOI

10.19154/njwls.v6i4.56/1

\section{Introduction}

$\mathrm{n}$ recent decades, more and more young women have been seeking placements as au pairs in Sweden. Compared with other national contexts (see, e.g., Anderson, 2000; Burikóva \& Miller, 2010; Macdonald, 2010), buying private child care services has until recently been an uncommon practice in Sweden, as in other Scandinavian welfare states. However, as a result of political initiatives such as the RUT tax deduction for domestic services, introduced in 2007, as well as increased global working migration (Parrenas, 2001; Ehrenreich \& Hochschild, 2002; Rodriguez, 2009), employing nannies and au pairs is becoming more common for well-off families in Sweden, as in other Scandinavian countries (Liversage et al., 2013; Bikova, 2015; Stubberud, 2015; Stenum, 2015; Eldén \& Anving, 2016).

\footnotetext{
${ }^{1}$ Terese Anving, Department of Sociology, Lund University, Box 114, 22100 Lund, Sweden.

E-mail: terese.anving@soc.lu.se
} 
The international definition of au pairing as 'cultural exchange' (European Agreement on Au Pairing, 1969), where young girls could enter the everyday life of a family and 'do light housework' as well as learn a new language, emerges in some Swedish regulations on au pairing as well as in the descriptions of the practice by the people involved (agencies, parents, au pairs themselves). However, the rules and regulations are contradictory: in reality, au pairing is simultaneously labeled as 'cultural exchange' and as work according to Swedish law (Calleman, 2010). Further, the regulations differ depending on whether the au pair comes from inside or outside the EU. The ambiguity of the rules and regulations in turn affects the practice of au pair work. We therefore argue that these more general precarious characteristics need to be examined in relation to the unclear rules and regulations that surround this work, as it is currently being enacted in Swedish families.

In this paper we look at the situation of au pairs in Sweden: the rules and regulations, and the consequences of how these are handled in practice in relation to feminist theories on care work (Davies, 1995; Mason, 1996). First, we discuss the regulations governing domestic work and au pairing, highlighting the different formal conditions for non-EU and intra-EU au pairs. Second, we look at how rules and regulations are understood, negotiated, and handled by the participating actors; the parents as employers and au pairs as employees. Of special interest here is how the tension between 'being on cultural exchange' and 'being a worker' is played out in practice, emerging in an interview study involving Swedish parents who have employed au pairs, and au pairs working in Swedish families.

\section{Domestic Work in Sweden: a Re-emerging Market}

Although au pairing has never been common in Sweden, employing private help to handle domestic chores has been a practice historically. At the beginning of the 1900s, when an increasing number of middle class women entered the paid labor market, hiring a maid or nanny was considered a practical solution to the problem of care work at home (Öberg, 1999; Platzer, 2006; Strollo, 2013). Although it was already then acknowledged that working conditions for domestic workers were poor, the low status of the work resulted in little actions being taken to improve the situation and protect the workers position vis-à-vis the employers. Domestic work was consequently, at an early stage, excluded from the general labor legislation and not seen as a regular profession (Calleman, 2011:125).

At the same time, domestic work was becoming less attractive to young Swedish women, as other possibilities emerged, such as jobs in the expanding industrial and public sectors. As a response, and to ensure that there would still be a good supply of domestic workers for Swedish families, laws and regulations were changed to make it easier to recruit migrant labor (de los Reyes, 1998). Domestic work was then also exempted from procedures that were meant to ensure the same working conditions for Swedish and migrant workers (Calleman, 2011:125). However, as the welfare state expanded, for example, with affordable daycare, child care allowances, and the right to parental leave (Bergqvist \& Nyberg, 2002), privately employed domestic workers became uncommon (Öberg, 1999; Strollo, 2013). After a couple of decades with practically no discussion of paid domestic work in Sweden, from the beginning of the 1990s, domestic work was once again on the agenda. In the debate, it was argued that allowing a tax deduction 
on domestic work would lead to gender equality by enabling women to pursue more demanding careers; it would also lead to more jobs, especially for migrant workers (Kvist $\&$ Petersson, 2010). When a right-wing coalition took office in 2006 , the so-called RUT ${ }^{1}$ deduction was one of the first reforms introduced (in 2007). The domestic work sector (cleaning and nanny companies) has since then grown rapidly (Gavanas, 2010; Eldén \& Anving, 2016), and in addition, a parallel sector in the form of an au pair market has emerged. Swedish families are thus increasingly employing domestic workers to help out with different kinds of care work in the home, including work on and around children.

Due to contradictory rules and regulations (which will be discussed in detail below), the au pair market is to a large extent invisible. This also means that it is extremely difficult to assess the true size of the market. Based primarily on contacts with au pair agencies, other researchers have calculated that the number of au pairs rose from practically zero at the beginning of the 1990 s to around 3000 by the end of the first decade in the 21 st century (Platzer, 2006; Calleman, 2010). However, these figures are already over 10 years old; our more recent-although qualitative-studies in the field indicate that the market is growing rapidly. Although there may be differences between countries, research in Denmark and Norway shows that the number of au pairs is growing in those countries, too. In Denmark, around 2400 au pair work permits were issued in 2011 (with au pairs coming mainly from the Philippines) (Liversage et al., 2013), and in Norway, around 1500 au pair visas were issued in 2013 (86\% to women from the Philippines). Research in the field indicates that the total number, including au pairs from within the EU, is likely to be twice as high (Stubberud, 2015).

Historically, the aim of domestic work legislation in Sweden has mainly been to recruit labor and make it easier through less strict regulations. This has been achieved by, for example, employment legislation, immigration policy, and tax reduction. Compared with other types of work and work regulation, one important difference is clear: weaker employment rights for domestic workers have always been justified in relation to the fact that the work is carried out in the employer's home, and the employer's right to privacy overrules the working conditions of the employee (Calleman, 2011:123). This, we argue, has consequences for au pairs in Sweden even today, as we shall see in the following.

\section{Previous Studies and Theoretical Framework}

As has been concluded in previous studies, the au pair situation is ambiguous on many levels. Au pairs often find themselves in a precarious position in terms of migration status (Rodriguez, 2009; Calleman, 2010), and the au pair role and the work au pairs perform are positioned in the midst of dichotomies such as private/public, worker/ 'one-in-the-family'/on 'cultural exchange', and work/emotion (see, e.g., Anderson, 2000; Parreñas, 2001; Ehrenreich \& Hochschild, 2002; Búriková \& Miller, 2010; MacDonald, 2010; Stenum, 2010). This, we argue, can be analyzed with the help of feminist theories on paid and unpaid care work, which is closely related to the discussion of care as work and care as emotion.

Definitions of care differ depending on societal and welfare context, and as a consequence, so do the structure of care provision (Leira, 1994:186). As mentioned above, with the emergence of the Swedish welfare state, care work increasingly became a collective concern, outsourced and organized by public means through, for example, public 
day care centers and elderly care (Lundqvist, 2011). This meant that parts of the unpaid care work previously performed by housewives and mothers were transformed into paid work, and as such, regulated by general working laws and agreements (although still mostly performed by women, less paid, and with lower status). The unpaid care work that remained was, according to the Swedish gender equality model, to be shared equally by men and women. While we know that the dual earner/dual carer model of Sweden has, in an international comparison, been successful, we also know that in practice, women still perform most of the care- and housework at home (see, e.g., Ahlberg et al., 2008; Roman \& Peterson, 2011). Interestingly, our study shows that one of the main arguments for parents to hire a nanny/au pair is the failure of the family to realize the gender equality ideal (Eldén \& Anving, 2016).

Davies (1995) argues that the distinctions made in welfare societies, between caring work as care performed within the home and on an unpaid basis, and care work, as a professional form of work, are problematic. It is based on the assumption of the former as being immersed with emotion and personal attachments, while the latter is thought to be possible to perform without emotions involved. In reality, also paid care work involves and necessitates emotional skills of 'building close relationships' with people involved in the practice (Davies, 1995:20).

Davies argument correlates well with discussions on care as work and care as emotion, and the dichotomy care for and care about (Finch \& Groves, 1983; Waerness, 1984; Graham, 1991). As many have argued, although this distinction has been fruitful in giving value to the unpaid and invisible work women do, it also reproduces ideas about the possibilities of separating emotions from work (Morgan, 1996). Conversely, studies of actual caring practices show that the performing of caring tasks, such as cleaning, washing, cooking, and child minding, is intertwined with emotions (DeVault, 1991; Leira, 1994; Mason, 1996; Anving, 2012).

Care work performed by au pairs inhabits a very specific position in relation to this. It is, to use Davies terminology, care work that is paid for (although it is much cheaper than other domestic services due to the fact that it is framed as cultural exchange; Cox, 2015), but it is also a form of caring work: it is supposed to replace the unpaid work that is expected to be done by parents, where, in addition to the caring tasks, emotional attachment is anticipated (Macdonald, 2010; Eldén \& Anving, 2016). Key here is, first, that this care work includes taking care of a child, something that bears strong moral expectations of emotional engagement (Tronto, 2002), and, second, that the caring activity is to be carried out in the home. The 'in-the-home' dimension is critical in the light of the history of domestic work in Sweden; as argued above, paid domestic work has historically not been regarded as regular work. Looking at the emerging domestic service market of au pairing through the tensions between care as paid/unpaid, and care as work/emotion, thus offers possibilities for analyzing the recognition and valuation of au pair work, both as it comes out in rules and regulations, and also in how the work is understood by the involved parties.

\section{Study and Methods}

The au pair market and practices of au pairing have been studied in the research project 'Care for Children in an era of Private Market Services: A Study of Nannies, Children 
and Parents'. ${ }^{2}$ The overall focus in the project has been to study family practices in families where parts of the care for children are purchased as a service on the private child care market, in the forms of nannies and au pairs.

In this study, interviews were conducted with the different actors involved: nannies/ au pairs, parents, and children $(n=73)^{3}$. The data analyzed for this paper comprise of interviews with au pairs (15) and interviews with parents of families that have employed au pairs (14 families). ${ }^{4}$ The au pairs' countries of origin were Germany, the U.K., Spain, Estonia, Macedonia, Taiwan, the U.S., Ukraine, and the Philippines. Seven were from EU countries, and eight from outside the EU. They were between 18 and 29 years old, and several had worked in other families than their present family, either in Sweden or elsewhere. In all, the experience they described came from working in more than 30 different families.

As for the parents, of the 14 families interviewed, 12 had employed au pairs from the EU (e.g., Austria, Estonia, Finland, Germany, Hungary, Ireland, Italy, Poland, Spain, etc.), while only two families had employed au pairs from outside the EU (Ukraine and the Philippines). Altogether, they had employed 51 au pairs over the years.

In interviews with the parents and au pairs, we asked about the procedure of hiring an au pair, as well as the working agreements between the two parties. The main part of the interviews was dedicated to talk about the actual work-practical and emotionalthat the au pairs perform in the families. In the analysis for this paper, we focus on the ways au pairs and the parents employing au pairs deal with the rules and regulations (formal and informal) of au pair work. We then relate this to how au pairing is carried out and experienced in practice. The interviews have been transcribed in full, and analyzed through extensive team discussions and coded in NVivo. The codes in focus for this article are 'EU au pair/non-EU au pair', 'taxes', 'work contract', and 'cultural exchange'.

In the attempt to get an overall view of the au pair market and the rules and regulations for au pairing in Sweden, we conducted interviews with au pair agencies (2), churches (3), the Swedish Migration Agency, and the Swedish tax Agency. In addition, we collected and analyzed different documents stating the rules for au pair work in Sweden, both information from authorities (the Tax Agency and the Migration Agency) and legal documents (the Domestic Work Act), and in addition information given on $\mathrm{Au}$ Pair agency websites. The focus of the analysis has been the content of the documents and on how they converge and contradict in different aspects.

\section{Au Pairing in Sweden: Unclear Rules and Regulations}

The reason why it is impossible to obtain the exact number of au pairs in Sweden (and other Nordic countries) is that different regulations cover different groups of au pairs, and while one of these groups (if here legally) is visible in official statistics, the other is not. The two groups are 1) au pairs from outside the EU, and 2) au pairs from within the EU. Applicants from the first group must obtain a work permit, and are thus recorded in Migration Agency statistics. ${ }^{5}$ The number of au pairs in Sweden with a work permit is relatively low, around 450 a year. The other group-au pairs from the EU-does not require a work permit due to the free movement of labor within the Union (Calleman, 2010); this means that they are not recorded in any data or registers. 


\section{Au Pairs From Outside the EU: Work Permits From the Migration Agency}

For applicants coming as an au pair from outside the EU, the regulations on paper are relatively clear. The au pair must apply for a work permit from the Migration Agency before entering the country. In order to obtain a work permit, the au pair must be between 18 and 30 years old, and have no accompanying children. Her workload is limited to 'light housework' and must not exceed 25 hours a week. She is also expected to study Swedish, with work and studies not exceeding 40 hours per week. The minimum wage is SEK 3500 per month before tax, and the employer is also required to pay for food and lodging. In order for the au pair to receive a work permit (which can be issued for one year), the working conditions must be stated by the host family in an offer of employment-which is not the same as a working contract. These working conditions must adhere to the regulations above (The Migration Agency, 2016a).

In the Migration Agency regulations for non-EU au pairs, the cultural exchange aspect of au pairing is emphasized in statements such as 'the purpose of the stay is to gain international experiences and to get the opportunity to learn Swedish language and learn about Swedish culture' (The Migration Agency, 2016a). This is also evident in the wording of what can hinder the issuing of a work permit, namely, if the au pair has worked as an au pair in another country before entering Sweden, which may 'be an indication of this being regular work as a nanny or alike, and not a stay as an au pair' (The Migration Agency, 2016a). Au pairing is thus simultaneously labeled 'work' (in that a work permit is issued) and set apart from 'regular work'.

\section{European au pairs in Sweden and the European Agreement on Au Pairing}

Au pairs from within the EU do not have to apply for a work permit because of the principle of free movement. Au pairs from within the EU who take up employment in Sweden are thus, on paper, not regulated by specific au pair regulations, but fall under the general regulations for EU workers. However, this is not the case for all au pairs working in Europe. On the contrary, most au pair work in Europe is regulated by the European Agreement on au pairing. The agreement was established in 1969 by the Council of Europe to oversee and protect the growing number of young people going abroad to work in families. As defined by the agreement, au pairs are on cultural exchange (Calleman 2010:73). ${ }^{6}$ In contrast to the other Nordic countries, Sweden has not signed this agreement.

The fact that Sweden has not signed the European agreement has been subject of discussion in the Parliament several times, most recently in 2007 when it was rejected with the argument that the au pair's position as a worker, as regulated by the Domestic Work Act (which we will turn to below), was legally better than it would be were Sweden to sign the European agreement (Riksdagen [Swedish Riksdag], 2007).

\section{All Au Pairs and the Domestic Work Act}

When the Domestic Work Act was passed in the 1970s, it was done so in a spirit of it soon becoming obsolete: paid domestic work was to be taken over by the public sector, 
and care and housework were to be shared equally between men and women (Lundqvist, 2011). However, it is evident today that what was then considered a labor of the past is today becoming one of the present. This means that the legislation that was thought to be outmoded already at its instigation is today regulating the working conditions of a growing number of workers.

All au pair work in Sweden, regardless of whether it is carried out by a non-EU or an EU au pair, is regulated by the Domestic Work Act. This means that all au pairs are legally considered workers. An immediate contradiction can thus be noted in relation to the regulation of work permits for non-EU au pairs as stated by the Migration Agency: here, au pairing is primarily referred to in terms of 'cultural exchange', and placed in direct opposition to 'regular work'.

The Domestic Work Act differs in important respects to general labor law in Sweden. For example, a written contract is not mandatory, longer and more flexible working hours are permitted (40 hours a week, which can be extended by 12 hours if involving the care of children), an employee can be dismissed without cause, inspection of the workplace (the employers home) is only allowed for special reasons (and is rare), and an employer cannot be punished for demanding too much overtime (Domestic Work Act, 1970:943; Calleman, 2011:131).

When the Domestic Work Act was introduced 1970, it was expected that labor unions would inform the groups concerned of the legislation and their rights. However, no such information is provided for au pairs today and very few of those concerned are even aware of the act (Calleman, 2011:137). The fact that very few domestic workers in Sweden generally ${ }^{7}$, and no au pairs in particular, belong to a trade union means that there is no regulation of minimum wages (which a collective agreement otherwise stipulates). Instead, domestic workers find themselves in a position where wages are negotiated directly between the employer and employee. This puts great pressure on the individual and his/her ability to negotiate and ensure that his/her rights are not violated. Filing a suit against an employer is therefore very unlikely and even more so if the employee is from another country, which is the case for au pairs (Calleman, 2011:132).

To sum up, one of the most striking paradoxes of au pair work is the tension of being defined simultaneously as 'cultural exchange' and work, a paradox that differentiates it from other kinds of work (Cox, 2015:2). For non-European au pairs, cultural exchange is the main principle of the regulations governing work permits. Further, the cultural exchange aspect is stressed in more informal information channels on au pairing in Sweden, such as websites for au pair placements. Here, the rules for non-EU au pairing are portrayed as covering all au pairs in Sweden. The actual rules regulating EU au pairs, the Domestic Work Act, do not state anything about cultural exchange. To complicate matters even further, the Domestic Work Act is also supposed to regulate non-EU au pairing-which explicitly puts it against the rules of the Migration Agency.

The cultural exchange/work-tension can further be related to different understandings of care work. While the work part of the au pair's tasks could easily be translated into ideas of paid care work, the being 'part of a family'-part (which, together with language training, is the quintessential part of cultural exchange) is more vaguely defined, but, through the use of 'family'-lingua, indeed signaling caring aspects more than care work (Davies, 1995; Stubberud, 2015).

The regulatory position of au pairs is thus extremely unclear. The au pair is not excluded from the labor market, but she is not really part of it either. The vagueness of 
au pairing, simultaneously defined as work and cultural exchange, often leads to rules being set aside and affects the way that au pairing is understood and 'done'.

\section{Au Pair Work in Practice: Regulations Set Aside}

Moving now to the interview data and the narratives of parents and au pairs, it becomes clear that while some of the rules and regulations are known to parents and au pairs, others are not. For example, while all parents know that tax must be paid, no one in our sample-neither parents nor au pairs-knew that au pairing is indeed defined as work under Swedish law.

Below, we will first discuss the understandings of-and consequences for-the two groups of EU and non-EU au pairs in Sweden. Second, we will look at how ideas of paid and unpaid work emerge in talk about tax and the value of the work au pairs do. Finally, by taking our point of departure in the question of written contracts between au pairs and families, we will look more closely at the actual working situation of au pairs, and how the tensions between 'cultural exchange'-being 'one of the family' - and being 'an employee' are played out in practice and can be related to the concepts of care and caring work.

\section{Differences between being a non-EU and an EU au pair}

Parents look for different qualifications and skills when deciding which au pair to employ, such as being 'child-loving', responsible, or speaking a different language (Eldén $\&$ Anving, 2016). More formal qualifications are also asked for. While there seemed to be no knowledge of the difference in rules regulating the work for non-EU and EU au pairs, all parents in our sample knew that they had to apply for a work permit at the Swedish Migration Agency if they wished to employ someone from outside the EU. Thus, most parents regarded being an EU citizen a key qualification: 'she has to be an EU citizen', one parent stated, so 'you don't have to deal with it'- 'it' meaning the paperwork involved in applying for a visa at the Migration Agency, which was considered troublesome and time-consuming by the parents. The fact that only two families in our sample currently employed an au pair from outside the EU is revealing, and indeed their experiences bear witness to the red tape involved.

According to Calleman (2010), the comparably low numbers of work permits issued for non-EU au pairs in Sweden can be explained by this fact. As a similar work force of au pairs wanting placement in Sweden can be found in EU countries-a work force that requires less (or no) administrative work on the part of employers-the motivation for parents to employ non-EU au pairs is low. This is especially the case after the expansion of the EU in 2004-2007, when more Eastern European countries joined the Union.

Looking at the narratives of the non-EU au pairs, the image of burdensome paperwork is confirmed. To address these issues-and to assure potential employers that nonEU au pairs are a worthwhile group to consider-some au pair groups have developed strategies. Filipina au pairs, who constitute a significant group in Denmark and Norway and a growing group in Sweden, ${ }^{8}$ organize themselves in networks and help each other find potential employers. 
Zoe is an au pair from the Philippines, who prior to her work in Sweden had worked in both Denmark and Norway. When her Danish au pair visa was about to expire, she got a new placement through her network of Filipina au pairs:

I have a friend, she just referred me and so quick, the family didn't really, we just only talked like twice in e-mail, but they were not really eager to call me, to hear my voice, to talk with me in Skype, to see me in Skype ... No, they just, 'Okay, we like you. Okay, you can start, can you start in this month?'

By acting as each other's intermediate, the au pairs also made it easier for the family to choose a non-EU au pair: it is a common practice for all the families in our sample to use previous au pairs to help find a new one, and for non-EU au pairs, this is especially important in finding a family or a new family after a previous position. It is also a way of trying to ensure that you end up in a 'good' family (Búriková, 2015).

However, moving from one country to another can also hinder an application for an au pair work permit. When Zoe was to sign her contract with the Swedish family, the au pair agency she consulted advised her to lie about her previous experience:

Zoe: I don't want really to tell about it, but they asked me to lie in my application. [...] They told me that I should write in the paper that I've never been in any Scandinavian country [...] Because the chances of getting [a work permit] are low by telling them that I've been in, in Denmark and Norway. You know, they told me to lie in the [contract], but I, for me, I don't have a choice, I need to do this, because if I don't do this I might have to go home, to the Philippines, and it's hard for me $[\ldots]$ to process the papers there.

Zoe's case shows how easily migration rules can be disregarded, since this market is poorly controlled. Zoe, too, was heavily dependent on the au pair work, as she was sending money back to her family in the Philippines. She therefore had no choice but to follow the advice of the agency.

Looking at the narratives of the EU au pairs, another form of precariousness emerges. While not facing the same threat of being denied a work permit, and while not (as often) being in a position of supporting a family at home, the invisibility of EU au pairs can also be experienced as precarious. Jane, for example, a German girl is well aware of her invisibility, and also that it can indeed potentially be problematic.

\footnotetext{
Interviewer: $[\ldots]$ you didn't have to, to get an au pair visa then, because you are an...

Jane: I'm a European citizen.

Interviewer: European citizen, right. Did you get, have to get something other, some other registration...?

Jane: No. No, authorities know that I exist in Sweden. I don't have a personnummer [social security number] either.

Interviewer: How do you solve that, in case, I mean, do you need to get in contact with the, like if you get... Or you haven't gotten ill yet?

Jane: No, not yet.

Interviewer: Do you know what will happen if, will they [the family] help you or...?

Jane: $\quad$ I have an, an insurance from, from in, in, yeah, from Germany, an extra insurance for one year for... Yeah, not for, how do you say it? No, it's just
} 
for, if you're sick you can go to the doctor and get medicine, but if you're not sick but just want to check I think you have to pay. [...] It was quite expensive though.

Jane has (on her grandfather's initiative and expense) prepared for one of the potentially problematic situations that could occur as a consequence of her invisibility, through buying herself a private health insurance. Other EU au pairs in our sample were less aware of the potential dangers of being invisible, and had subsequently not taken the same precautions as Jane. However, what Jane could do nothing about was the fact that the workload that the family requested of her by far exceeded the 25 hours they had initially agreed upon. Complaining to the authorities when working agreements are breached is in practice very hard also for non-EU au pairs, but for EU au pairs, there are not even in theory any possibility of complaining, due to their invisibility.

The invisibility of EU au pairs consequently puts them in a vulnerable position, with nowhere to turn when problematic situations arises. At the same time, despite being visible in official statistics, non-EU au pairs are in many ways in a more precarious position than EU au pairs. They are a less attractive labor force, they rely heavily on informal networks and agencies (who sometimes place them in the risky position of lying to the Migration Agency), and they are limited by visa requirements. They are also often more financially dependent on the work, as they are more likely to be sending home money to relatives (Rodriguez, 2009; Guevarra, 2010). ${ }^{9}$

\section{Paying for Care Work: Talk About Taxes}

As au pairs in Sweden are legally regarded as workers, they should pay tax, and their employer should pay employment tax. All participating parents knew this, and in that sense, they were very aware of au pair work being a form of paid work. Still not everyone chose to follow the law: about half of the families stated that they paid employment tax for their au pair. While some thought that the tax rules were too complicated, others found them easy to follow and regarded it as self-evident that they should pay tax. Some stated that paying tax would make the au pair too expensive, an extra cost they were not willing to bear. Paying tax also meant 'making the au pair official': if the family employed an au pair from the EU, reporting her work to the Tax Agency was in effect the only way authorities would find out.

Gertrud and her husband were very keen to 'do it right' and to treat au pair work as any other kind of work, so they tried to gather all the information they could. Gertrud contacted the Tax Agency, but they could not answer any of her questions, she says:

Gertrud: And then I said [to the Tax Agency], 'You don't get this question very often, do you?' I said, 'Not many people pay au pairs officially and above board in this country, do they?' No, on that they could agree, that it was like that, that they were not asked the question very often.

Other parents also testified to the difficulty of obtaining information on the right way to do things. When Martina and Mikael were about to employ their first au pair, they made use of an agency since they were keen to do things correctly from the outset, and 
they assumed that the agency would help. However, the agency could not answer any questions about tax. The same agency also gave another family in our sample the wrong information, which led to the au pair not being able to pay tax or receive social security number:

Brita: And then he [the Agent] said that in Sweden it is like, in the field of legislation, tax wise, we have a gray zone, where they recommend that you don't pay tax, but rather regard the money as pocket money.

The agencies' unwillingness to find out and inform parents about the rules of au pair work can be interpreted as a way of utilizing the vagueness of the rules, and thus make the service cheaper and more attractive to the parents. When the parents wish to adhere to the rules and treat au pair work in accordance to working regulations, they are advised not to.

Other parents made a conscious decision not to pay tax, despite the fact that they knew they should. Stefan who, together with his wife, had employed several au pairs over the years was indeed somewhat concerned that his tax avoidance would be exposed one day, as he is a politician. Stefan also justified his decision with the argument that paying tax would make the au pair too expensive, and that it also would mean less money for the au pair since she would have to pay tax on the SEK 3500 she earned.

For EU au pairs, the risk of being found out by the Tax Agency that they are working in the country is very small. As noted above, the free movement of labor means that they are not registered anywhere. However, an incentive for au pairs and families to report the stay to the authorities is if the au pair needs a social security number. This is necessary if you, for example, want to apply for an account at a Swedish bank, which many au pairs want. However, some families prefer to open an extra account in their own name, or pay the au pair in cash.

Another motivation for families to make the au pair 'official' is to be able to enroll her in a language course: if the au pair has a social security number, she can attend language courses at SFI (Swedish For Immigrants), a free, state-sponsored program for immigrants. Otherwise, the family would have to pay for a much more expensive private language school. In that sense, the parents' adherence to the rules also seems to depend on the potential benefits for themselves: making the au pair official can reduce the cost for the family. Linda, an EU au pair, lived in a host family that did not want to pay for a language course, which meant that she had to get a social security number to enroll on the SFI course:

Linda: [The parents] didn't want to pay for it. I mean, I think there's a rule, I knew that before, after I moved all my documents and, but there's a rule, if you are an au pair here or in any country, that you must take, like, a free course of the language of the country and they didn't do that.

Linda then had to persuade the parents to give her the work contract she needed in order to obtain a social security number, so that she could apply for the SFI course. Getting onto a language class is very important for the au pairs, not primarily for 'cultural exchange', but because an increasing number of au pairs, EU and non-EU, intend to find a regular job and remain in Sweden after finishing their au pair placement. 
In sum, the tax rules that apply to au pair work are interpreted differently, and while some do try honestly to find out about and follow the rules, others-not least the agencies-intentionally break them. This, we argue, again indicates a lack of regulation of au pair work, and also that au pairing is a form of work that few are interested in having regulated. Most importantly, the talk about paying tax as making the au pair's work too expensive signals that the parents are not willing to pay the (already very low) cost for the service they get. Drawing on the argument of Davies (1995), the kind of work au pairs do are the caring work part of the dichotomy: the unpaid work expected to be done by parents (mothers). This, we argue, seems to further impede on parents willingness to pay for this kind of work.

\section{Work contracts}

The tension between care work and caring work is also visible in the ways contract agreements are discussed and handled by the parents and the au pairs. According to the Migration Agency's regulations for non-EU au pairs, the employing family must present a 'work offer' in line with the rules set by the authorities for the au pair to be granted a work permit; however, there is no need for a legally binding, signed work contract. Nor does the Domestic Work Act demand one. In our interviews, questions about work contracts resulted in different reactions. Some families had drawn up contracts, some had not, and some au pairs were unsure whether they had done so or not. A common reaction of parents was to downplay the importance of a contract, while au pairs more often stated that they wished to have some form of written contract.

However, some parents, especially those who had considerable experience employing au pairs, seemed keen on having a signed contract. 'Mistakes' in the past had taught them to use the contract to ensure that the au pair knew what was expected of her. Contracts could be used to specify work tasks and hours, and sometimes further conditions were added. Brita and Bjarne, for example, whose first au pair was found through an agency, used the agency contract as a template when they independently employed their next au pair. However, they chose to add some things to the original contract:

Brita: It says that she can't breach the contract, that it's a commitment that she has taken on, and that she could get, yes, and maybe that was a little mean, but I wrote that - since the last one [au pair] left us-I wrote that: 'I am aware that it will cause difficulties for the family if I leave before the end of the contract, and there could be a discussion about possible compensation'. I just wrote that, and we wouldn't do anything like that really, but I guess it's quite common that you do this, you just write something like that. So that she is determined to stay for the whole time.

The contract was used as a means to put pressure on the au pair to stay for the whole contracted period, and there was even an underlying threat of her being responsible for compensation if she did not see out her contract. Although Brita said that the family would never actually demand compensation, this was not known to the au pair.

Alma and August, a couple who had also employed several au pairs, used the contract to get their au pair to do more work than the stated 'rules': 
Alma: That I learnt from another family, if they [au pairs] get paid SEK 4000, then I don't want any complaints about the hours they have to work [...] Not that they have to work themselves to death, but show some good will.

Some parents saw the contract as a way to strengthen their position in relation to the au pair, to tie her to the family, and to ensure that she was 'flexible' and willing to adjust to the family's needs, a much sought after ability in au pairs. This way of using the contract could be understood as a way of strengthening the caring part of the work, that is, to ensure a constant and all encompassing engagement of the au pair.

$\mathrm{Au}$ pairs were often more eager to have a written contract than host families, as this-at least on paper-gave them a feeling of being in control of the work. A contract could be seen as a means of establishing a relationship that more resembled that between a worker and an employer:

Elin: I was actually the one that asked for a contract. Just to have something official. Because I started with the agency and then we did it via the website, which just seemed really vague and I wanted something on paper, so we just wrote down... [...] The contract basically just states what my duties are and my free time, what I get paid and ...

Interviewer: How many hours do you have to work?

Elin: $\quad$ Yeah. About, I think ... I'm not sure if the exact hours were on there. No. [...] But sort of a general overview of what it's going to be and then just the signatures.

Although Elin's contract does not say anything about the precise hours, or the maximum hours, she should work, she nevertheless see it as important and as giving her a sense of a strengthened position in relation to the family. A working contract puts the work aspect of care at the center of the relationship, and can be seen as an attempt of the au pair to counter the family's wants for unlimited caring.

However, having a contract is in no way a guarantee for a more 'work like' situation with limited hours and defined tasks. Several au pairs in our study told about contracts stating one thing, but the actual work turning out to be something else. While most contracts used the term 'light housework', many au pairs found themselves being asked to clean the whole house every week, take care of the laundry, make food for the family several days a week, on top of taking care of the children in the mornings and afternoons on weekdays, as well as some evenings and on weekends-work tasks that by far exceeded the 25 hours often stated in the contracts.

The possibility of asking for a contract, or to negotiate its content, further differed among au pairs. While some felt confident to point out that the work they did exceeded the contracted agreement, others felt they had too much to lose if they fell out with the family. In her former family, Vivianne, an au pair from the Philippines, was forced to work much more than the 25 hours stated in the work permit that they had sent to the Migration Agency. Vivianne had the main responsibility for the whole household as well as the children, and the working conditions were hard. In the interview, Vivianne told about one incident when she was asked to clean the windows. Scared by the fact that the windows were so high up in the building, Vivianne tried to talk to the host mother to relieve her of the task since, she argued, it could not be considered 'light housework'. 
The mother refused to listen, but Vivianne insisted, and wrote her a note. After that, the mother did not talk to her for several days. Vivianne was really scared about the incident: she did not want to complain, she did not 'want them to be mad or upset', but she really felt that she could not clean those windows. When asked why she did not leave the family after this incident, she said that she was under the impression that she, according to the contract, was not 'allowed to leave her job'. Also, since Vivianne was from outside the EU, leaving the family would mean a difficult job of finding another family to work for, or else she would have to return home (and could no longer support her family).

Parents general downplaying of contracts, or use of contracts to further control the au pair, and au pairs' use of contracts as a means to strengthen their position in the family can be interpreted in relation to the tension between caring work and care work identified by Davies (1995). The way contracts are used by parents show how the caring aspect is enforced with expectations that the au pair has a constant engagement in the family, and that she is 'flexible' in relation to working tasks and hours. Au pairs, on the other hand, try to emphasize the care work-dimension and use contracts to define the working tasks and working hours, and thus, try to define the practice of au pairing more as regulated work. However, the way contracts are used rarely regulates the work in a way that strengthens and protects the au pair's position, but rather that of the parents.

\section{'Cultural exchange' vs. 'work'}

The au pair's working conditions are further influenced by being neither one thing nor the other: an 'employee', 'on cultural exchange', or 'one of the family' (see also Anderson, 2000; Búrikova \& Miller, 2010; Stubberud, 2015). As we have discussed, the regulations of the Migration Agency and Domestic Work Act are contradictory: au pairing is sometimes constructed as 'cultural exchange', other times as 'work'. This contradiction also emerges in the descriptions of au pairing in the interviews. Shifting between different definitions of au pairing could be used to maintain the overtime au pairs work-no matter what a contract, if one exists, might state. Host mother Alma, for example, is initially very frank in the interview about why her family has an au pair: the au pair is not there for cultural exchange, but to work.

Alma: Some who want to be au pairs think that they're going to be like exchange students. So then I try to be clear and say that if we were just interested in cultural exchange, and the only reason you come here is that you want to learn Swedish, then I would have taken an exchange student and not an au pair. It's a very big difference.

In this part of the interview, then, the cultural exchange aspect of au pairing is dismissed: the au pair is primarily a worker, and it is absolutely crucial to Alma that she understands this from the outset. But the work aspect can in other instances be downplayed. When, for example, talking about the relationship the au pair is forming with the children, the parents can describe the au pair as a 'big sister', as someone they want to feel is like 'part of the family', stressing the caring work aspects of the situation.

Further, when being defined as 'part of the family', the work agreements and conditions seem easier to put aside. This, paradoxically, can result in demands for more work from the au pair. When Alma, for example, later in the interview describes the evening 
dinner routine, the au pair is no longer defined as a worker. According to their working agreement, the au pair should not be involved in the dinner routine, but she is. This is explained by her now being 'part of the family':

Alma: Then it is like we say, then it is like a family responsibility. The grown-ups that are at home help out.

Here, the au pair is instead defined as a part of the family rather than a worker. The household tasks they expect her to do are expected precisely because she is now defined as one of the adults in the family, and there is consequently no exact time for when the work ends.

This ambiguity of being 'one of the family'/on 'cultural exchange' while at the same time a worker is often explicitly spoken about as problematic by au pairs:

Gaby: They, and that's a thing that I don't think they realize sometimes, is that I, I do a lot when I'm not on duty too, even though it has, I'm not directly with the kids, doing things with the kids off duty ... I don't think that they, they count that as... me working. But it's, it's almost more work, because I ... I'm taken away from my, myself, to do things, which I don't mind doing, but I just wish that they would see it [laughing]. [...] I kind of told the host, my host mum about it, just ... 'cause they have like my designated hours and I have a schedule and everything, but it's, it's only the times that I'm with the kids ...

The difficulty of never being off duty, being part of the family, and of working for them, is a cause of considerable frustration. Gaby tells about all the work she does that the parents do not see and recognize as work. Instead, they argue that she is doing too little work, since for them living with the family and being in the home during the day also means that Gaby ought to clear up, empty the dishwasher, buy milk if needed and so on. What they are asking for is for her to be attuned to the needs of the family (Mason, 1996) - an emotional caring work activity, which cannot easily be translated into specific tasks with a clear beginning and ending.

Thanks to the pending between 'working' and 'being on cultural exchange'/'one of the family', the au pair's activity is not easily categorized as either care work or caring work (Davies, 1995). The same tasks can be framed differently, as work time, or as family time, resulting most often in the au pair carrying out more work than agreed upon.

\section{Conclusions}

As we have discussed throughout this paper, the rules and regulations that apply to au pair work in Sweden-the Swedish Migration Agency rules for non-EU au pairs and the Domestic Work Act for all au pairs-are contradictory and unclear. Non-EU au pairs, if not here irregularly, are visible in statistics since they have to apply for a work permit; however, EU au pairs are invisible. The fact that most au pairs are invisible might be a further reason why this group of workers, despite their often harsh working conditions, has not received much attention, either from labor market authorities such as labor unions, or from the Tax Agency. 
Others have argued that part of the problem of au pairing is that au pairs perform domestic work while not officially being considered as domestic workers (Stubberud, 2015:122). In the case of Sweden, this is only partly true: here, au pairs are indeed legally considered workers under the Domestic Work Act. In practice, however, no one is aware of the au pairs' position as workers. The contradictory writings in rules and regulations of au pairs being sometimes defined as workers and in other instances as on 'cultural exchange' make it very hard for the people involved in the practice to do it right. It has previously been argued that au pairs either do not know their rights, or are unable to claim them (Búrikóva, 2015:39). This is partly confirmed by our research, but it is also complicated by the fact that the regulations themselves are unclear. We see in our sample that au pairs might very well think that they know their rights-such as that they should work a limited number of hours, or that they have the right to attend a language course-but in fact this applies only to non-EU au pairs, as EU au pairs are regulated solely by the Domestic Work Act.

In Sweden, au pairs are thus not completely excluded from the labor market, but they are not really part of it either. There are no au pair labor unions, which means, first, that there is no one to turn to if a problematic situation arises ${ }^{10}$; second, no one checks or oversees the work, or has insight at the work place; and, third, there is no collective agreement regarding wages, in contrast to all other occupations in Sweden.

As we have seen, the precariousness of the two different categories of au pairs differs. When it comes to negotiating your position in the family, the non-EU au pairs comes out as more vulnerable and more dependent on external factors such as migration policies and expectations from families left behind. EU-au pairs, on the other hand, are totally invisible as they are not registered anywhere. Since this group seems to be the largest group of au pairs in Sweden, their invisibility is worrying, as it indicates a growing presence of a new sector of completely unregulated domestic work.

The au pair is at the same time expected to do care work and caring work (Davies, 1995), and as her work is carried out within the home, the situation becomes even more ambiguous. The division between unpaid and paid for care work in Sweden situated the former to the setting of the home. As we argued above, this has resulted in an unwillingness to regulate the paid work that is actually taking place within the home. In Sweden, paid domestic work was for a long time regarded as a profession of the past. The Domestic Work Act that regulates it was even at its instigation thought to be obsolescent. Today, however, it is once again relevant for a growing group of migrant women who are often already in a precarious position. The need for separate-and weakerlabor legislation for domestic work was historically justified by arguments about the special character of the work-it was carried out in the homes of other people. We would argue, however, that the 'carried out in the home' dimension should rather justify even stronger labor law protection for workers in such professions.

\section{References}

Ahlberg, J. Roman, C. \& Duncan, S. (2008). Actualizing the 'democratic family'?: Swedish policy rhetoric versus family practices, Social Politics 15(1): 79-100. doi: https:// doi.org/10.1093/sp/jxn003. 
Anderson, B. (2000). Doing the Dirty work? The Global Politics of Domestic Labour, London: Zed Books.

Anving, T. (2012). Måltidens paradoxer: om klass och kön i vardagens familiepraktiker [Meal paradoxes: class and gender in everyday family practices], Diss. Lund : Lunds universitet.

Bergqvist, C. \& Nyberg, A. (2002) Welfare State Restructuring and Child Care in Sweden, pp. 287-307 in Michel, S. \& Mahon, S. (eds). Child care policy at the crossroads, New York: Routledge.

Bikova, M. (2010). The Snake in the Grass of Gender Equality. Au-Pairing in Women-Friendly Norway, pp. 49-68 in Isaksen, L. W. (ed.). Global care work: gender and migration in Nordic societies. Lund: Nordic Academic Press.

Bikova, M. (2015). In a Minefield of Transnational Social Relations: Filipino Au Pairs Between Moral Obligations and Personal Ambitions, pp. 87-103 in Cox, R. (ed.). Au Pairs' Lives in Global Context; Sisters or Servants?. Basingstoke: Palgrave Macmillan. doi: http://dx.doi.org/10.1057/9781137377487 6 .

Búriková, Z. \& Miller, D. (2010). Au Pair, Cambridge: Polity Press.

Búriková, Z. (2015). 'Good Families' and the Shadows of Servitude: Au Pair Gossip and Norms of Au Pair Employment, pp. 36-52 in Cox, R. (ed.). Au Pairs' Lives in Global Context; Sisters or Servants? Basingstoke: Palgrave Macmillan. doi: http://dx.doi. org/10.1057/9781137377487 3 .

Calleman, C. (2007). Ett riktigt arbete?: om regleringen av hushållstiänster [A real work?: About the regulation of domestic work], Säter: Pang förlag.

Calleman, C. (2010). Cultural exchange or cheap domestic Labour? Constructions of 'au pair' in four Nordic countries, pp. 69-96 in Isaksen, L. W. (ed). Global care work: gender and migration in Nordic societies, Lund: Nordic Academic Press.

Calleman, C. (2011). Domestic Services in a Land of Equality: The Case of Sweden, Canadian Journal of Women and the Law, 23(1): 121-139. doi: http://dx.doi.org/10.3138/ cjwl.23.1.121.

Cox, R. (2015). Introduction, pp. 1-15 in Cox, R. (ed.). Au pairs' lives in global context; sisters or servants? Basingstoke: Palgrave Macmillan. doi: http://dx.doi.org/10.1057/978 1137377487.0005.

Davies, C. (1995). Competence versus Care? Gender and Caring Work Revisited. Acta Sociologica 38(1): 17-31. doi: http://dx.doi.org/10.1177/000169939503800103.

de los Reyes, P. (1998). I skärningspunkten mellan genus och etnicitet [Intersections between gender and ethnicity], Arbetsmarknad \& arbetsliv [Labour market \& Working life], 4(1): 13-31.

DeVault, M. L. (1991). Feeding the family: the social organization of caring as gendered work, Chicago: University of Chicago Press.

Eldén, S. \& Anving, T. (2016). New ways of doing the 'good' and gender equal family: Parents employing nannies and au pairs in Sweden, Sociological Research Online, 21(4), 2. doi: http://dx.doi.org/10.5153/sro.4163.

Ehrenreich, B. \& Hochschild, A. R. (ed.) (2002). Global Woman. Nannies, Maids, and Sex Workers in the New Economy, London: Granta books.

Finch, J. \& Groves, D. (ed.) (1983). The labour of love: Women, work and caring, London: Routledge.

Gavanas, A. (2010). Who Cleans the Welfare State? Migration, Informalization, Social Exclusion and Domestic Services in Stockholm, Stockholm: Institute for Futures Studies.

Graham, H. (1991). The Concept of caring in feminist research: the case of domestic service, Sociology, 25(1): 61-78. doi: http://dx.doi.org/10.1177/0038038591025001004.

Guevarra, A. R. (2010). Marketing Dreams, Manufacturing Heroes, [Electronic Resource] Rutgers University Press. 
Kvist, E. \& Peterson, E. (2010). What Has Gender Equality Got to Do with It? An Analysis of Policy debates Surrounding Domestic Services in the Welfare States of Spain and Sweden, Nordic Journal of Feminist and Gender Research, 18(3): 185-203. doi: http://dx.doi.org/ 10.1080/08038740.2010.498326.

Kvist, E. (2013). A Booming Market of Precarious Work: Selling Domestic Services in WomenFriendly Sweden, pp. 214-233 in Gunnarsson, A. (ed). Tracing the Women-Friendly Welfare State: Gender Politics of Everyday Life in Sweden, Stockholm: Makadam.

Liversage, A., Bille, R. \& Jakobsen, V. (2013). Den Danske au-pair ordning. En kvalitativ og kvantitativ undersøgels [The Danish au pair order. A qualitative and Quantitative analysis] 13:02. København: SFI - Det Nationale Forskningscenter for Velfærd [SFI - The Danish National Center for Social Research].

Leira, A. (1994). Concepts of Caring: Loving, Thinking, and Doing, Social Service Review, 68(2): 185-201. doi: http://dx.doi.org/10.1086/604046.

Lundqvist, Å. (2011). Family policy paradoxes: gender equality and labour market regulation in Sweden, 1930-2010, Bristol: Policy. doi: http://dx.doi.org/10.1332/policypress/9781847424556.001.0001.

Macdonald, C. L. (2010). Shadow Mothers. Nannies, Au Pairs, and the Micropolitics of Mothering. Berkeley: University of California Press.

Mason, J. (1996). Gender, care and sensibility in family and kin relationships, pp. 15-36 in Holland, J. \& Atkins, L. (ed) Sex, Sensibility and the Gendered Body, London: Macmillan. doi: http://dx.doi.org/10.1007/978-1-349-24536-9 2.

Morgan, David H. J. (1996). Family Connections. An Introduction to Family Studies, Cambridge: Polity Press.

Parreñas, R. S. (2001). Servants of Globalization. Women, Migration, and Domestic Work. Stanford, California: Stanford University Press.

Platzer E. (2006). From Public Responsibility and Back Again: The New Domestic Services in Sweden, Gender \& History. 18(2): 211-221. doi: http://dx.doi.org/10.1111/j.14680424.2006.00426.x.

Rodriguez, R. M. (2009). Challanging the Limits Of the Law: Filipina Migrant Workers' Transnational Struggles In the World for Protection and Social Justice, pp. 49-63 in Lindio-McGovern, L. \& Wallimann, I. (ed.). Globalization and Third World Women: Exploitation, Coping and Resistance. Farnham: Ashgate.

Roman, C. \& Peterson, H. (2011). Familier i tiden: Förhandling, kön och gränslöst arbete [Modern Families: Negotiations, gender and Infinate Work], Umeå: Boréa.

Stenum, H. (2010). Au-Pair Migration and New Inequalities. The Transnational Production of Corruption, pp. 23-48 in Isaksen, L. W. (ed). Global care work: gender and migration in Nordic societies, Lund: Nordic Academic Press.

Stenum, H. (2015). Bane and Boon; Gains and Pains; Dos and Don'ts ... Moral Economy and Female Bodies in Au Pair Migration, pp. 104-120 in Cox, R. (ed.). Au Pairs' Lives in Global Context; Sisters or Servants?. Basingstoke: Palgrave Macmillan. doi: http://dx.doi. org/10.1057/9781137377487 7.

Strollo, E. (2013). Det städade folkhemmet: tyskfödda hembiträden i efterkrigstidens Sverige [German domestic workers in the 'people's home' of Sweden], Diss. Linköping: Linköpings universitet, 2013.

Stubberud, E. (2015). 'It's Not Much': Affectice (Boundary) Work in the Au Pair Scheme, pp. 121-135 in Cox, R. (ed.). Au Pairs' Lives in Global Context; Sisters or Servants?. Basingstoke: Palgrave Macmillan. doi: http://dx.doi.org/10.1057/9781137377487 8.

Tronto, J. C. (2002). The 'Nanny' Question in Feminism, Hypatia 17(2): 34-51. doi: http://dx.doi.org/10.1111/j.1527-2001.2002.tb00764.x.

Wærness, K. (1984). The Rationality of Caring. Economic and Industrial Democracy 5(2): 185-211. doi: http://dx.doi.org/10.1177/0143831X8452003. 
Öberg, L. (1999). Ett socialdemokratiskt dilemma: från hembiträdesfråga till pigdebatt [A Social Democratic dilemma: maidservants and maid debates], pp. 159-199 in Florin C et al (eds.). Kvinnor mot kvinnor: om systerskapets svårigheter [Women against women: about the difficulties of sisterhood]. Stockholm: Norstedts Förlag.

\section{Internet sources}

European Agreement on 'au pair' Placement and Protocol therto (1969). https://rm.coe. int/CoERMPublic CommonSearchServices/DisplayDCTMContent? documentId= 090000168007231c (2016-05-25).

FOA: Baggrund: FOA og au pair [FOA: Background: FOA and au pairs] (2016). https:// www.foa.dk/Forbund/Temaer/A-I/Au-pair-i-Danmark/Baggrund-FOA-og-au-pair (201605-25).

Migrationsverket: Att anställa en au pair [The Migration Agency: Hiring an au pair] (2016a). http://www.migrationsverket.se/Andra-aktorer/Arbetsgivare/Sarskilda-regler-for-vissayrken-och-lander/Au-pair.html (2016-05-25).

Migrationsverket: Översikt av beviljade arbets- och uppehållstillstånd åren 2005-2015 [The Migration Agency: Overview of approved work- and residence permits year 2005-2015] (2016b). http://www.migrationsverket.se/download/18.2bbf7de914c17a2ed265510/143 5761316063/\%C3\%96versikt-2005-2015.pdf (2016-05-25)

Sveriges riksdag: Europeiska au pair-avtalet. Motion 2007/08:U325, Birgitta Ohlsson (L) [The Swedish Riksdag: European Au Pair Agreement. Bill 2007/08:U325, Birgitta Ohlsson (L)] (2007). http://www.riksdagen.se/sv/Dokument-Lagar/Forslag/Motioner/Europeiskaau-pair-avtalet GV02U325/?text=true (2016-05-25).

Sveriges Riksdag: Lag om husligt arbete 1970:943 [The Swedish Parliament: The Domestic Work Act 1970:943] (2016). http://www.riksdagen.se/sv/Dokument-Lagar/Lagar/ Svenskforfattningssamling/Lag-1970943-om-arbetstid-m sfs-1970-943/ (2016-05-25).

\section{Notes}

${ }^{1}$ RUT (an acronym for 'Rengöring, Underhåll, Tvätt'/Cleaning, Maintenance, Washing) enables taxpayers to make a deduction for domestic services, up to $50 \%$ (in January 2016 reduced to $30 \%$ ) of the labor cost of the service, up to a stated limit (Skatteverket, 2015).

2 This project is funded by The Swedish Foundation for Humanities and Social Sciences (RJ P13-0603:1) and has been approved by the Ethical Review Board [Dnr 2014/94].

${ }^{3}$ In all, the study consists of interviews with au pairs (26), parents (28), and children (19) as well as with nanny companies (6), au pair agencies (2), churches (3), the Swedish Migration Agency, and the Swedish tax Agency.

${ }^{4}$ Seven of the interviews with parents were couple interviews, with both the mother and father present; the remainder were individual interviews, with two participating fathers (nine of the 28 parents were thus men). Altogether the participants came from 21 families, of whom 14 had employed au pairs (some had employed nannies before that).

${ }^{5}$ In 2014, the number of work permits issued to au pairs from outside the EU was 493 (this figure also includes interns). This indicates a growth in the last couple of years (390 work permits in 2011) (The Migration Agency, 2016b).

${ }^{6}$ Even if the agreement focused on European exchange, it was also applicable to au pairs who were not European citizens. 
7 Even domestic workers employed by agencies, which is more common since the RUT deduction, rarely belong to a union (Kvist, 2013).

${ }^{8}$ The Swedish ban on au pairs from the Philippines was lifted in 2012. In Denmark, au pairs are organized in the trade union FOA (FOA, 2016).

${ }^{9}$ However, after the most recent economic crisis, an increasing number of intra-EU au pairs-in our sample we have Southern and Eastern European au pairs-also find themselves in a situation where they are supporting their families at home.

10 However, research in other Nordic countries shows that when au pairs make complaints to authorities, it has rarely any consequences for the employing families (Liversage et al., 2013). 